\title{
Preliminary Study: Profile of Critical and Creative Thinking in Undergraduate Students of Biology Education Study Program, Universitas Negeri Yogyakarta
}

\author{
Rifqi Rasis ${ }^{1, *}$ Paidi $^{2}$ \\ ${ }^{1}$ Master of Biology Education, Faculty of Mathematics and Natural Sciences, Universitas Negeri Yogyakarta, \\ Indonesia \\ ${ }^{2}$ Department of Biology Education, Faculty of Mathematics and Natural Sciences, Universitas Negeri \\ Yogyakarta, Indonesia \\ *Corresponding author. Email: rifqirasis@gmail.com
}

\begin{abstract}
This research is a preliminary study conducted to describe the profile of critical and creative thinking of undergraduate students of biology education at Universitas Negeri Yogyakarta (YSU). This research was conducted on 59 students who have active status as undergraduate students of the biology education program at YSU. The instrument used was a habit of mind instrument of critical and creative thinking in the form of a Likert scale questionnaire. After obtaining the data, then the data were analyzed descriptively. The results showed that the students' critical thinking and creative thinking scores were in the fair category.
\end{abstract}

Keywords: Critical thinking, creative thinking, Undergraduate student, Biology education.

\section{INTRODUCTION}

In this era of the industrial revolution 4.0 , it has become an obligation for someone to master complex competencies and abilities in order to face new challenges, new problems, new ways of life, and new career opportunities. The 21 st century is marked by the era of the industrial revolution 4.0 which is also known as the century of openness. In this 21 st century, every individual is required to be qualified in all aspects, for example, in thinking processes, drafting concepts, and / or in carrying out any other actions [2]. So, in the world of education a breakthrough is needed in the form of a new paradigm in facing these new challenges [2]. One way is to equip students with a number of new skills needed to be able to face changes and various kinds of challenges in this century [3].

The National Education Association (NEA) identifies the skills one should have in the 21 st century as The 4Cs skills [4]. These The 4Cs skills are; (1) critical thinking skills, (2) creative thinking skills, (3) communication skills, and (4) collaboration skills. Today, if the students want to compete in a globalized society, the NEA suggests that they must become proficient communicators, be both creators and critical thinkers, and collaborators [4]. In line with this, Assessment and Teaching of 21st Century Skills (ATC21S) describes the skills possessed in the 21st century must be supported by a set of knowledge, values, attitudes, skills, and ethics. This 21 st century skill concept has become known as the KSAVE model (Knowledge, Skill, Attitude, Value and Ethics). 21st century skills, by this model are categorized into 4 categories; (1) the way of thinking includes creative thinking, innovative thinking, critical thinking, problem solving, and decision making, as well as learning and innovation, (2) way of working includes communication skills and collaboration skills, (3) tools for working include technology and communication (ICT) literacy as well as information literacy and (4) skills that is important for living in the world in the form of skills based on awareness as citizens, awareness to always develop life and career, and have a spirit of responsibility as individual and social beings [5].

Partnership for 21st Century Learning also designs a framework in which it explains what skills, knowledge and expertise students must master in order 
to succeed in their work and life. This framework is known as the Framework for 21st Century Learning. In this framework outlined the outcomes and support systems for 21 st century learners including; the main subjects and themes of 21 st century issues, learning skills and innovations which include; creativity, innovation, critical thinking, problem solving, communication and collaboration, information skills, media and technology, and life and career skills. These learning and innovation skills can differentiate between learners who are ready to face complex lives and those who are not [6].

From several definitions of skills that must be mastered as stated above, critical thinking and creative thinking have become a necessity for everyone in the 21 st century and also as an era of this 4.0 industrial revolution [4] [5] [6]. No exception to students, critical thinking and creative thinking are also essential needs for students. So that in the world of education, educators are required to develop critical and creative thinking skills in students. Because someone does not have this skill from birth, but this skill is obtained from the learning process [7].

In order to keep up with the advancement of science and technology that continues to develop, educational institutions must also continue to change and adapt their curriculum to existing developments. [8]. One of them is higher education, which is an educational institution that is responsible for producing high-quality graduates in the future. Through a good quality education, it is hoped that it can produce high quality human resources who are able to face various problems in this century [9]. The characteristics of quality graduates are one of them who has the skills to think critically [10] and think creatively [10][11]. Critical thinking and creative thinking in students can be developed during the lecture process in higher education [12] [13].

At the time of developing students' critical and creative thinking skills, the first step that should be taken first is knowing the initial description of the critical thinking and creative thinking profile of students. One way that can be used to reveal these thinking skills is by looking at the profiles of their critical thinking and creative thinking habits [10]. So far there have not been many studies describe the profile of critical and creative thinking in students in higher education institutions. Especially at Universitas Negeri Yogyakarta (YSU), research that aims to reveal the profile of critical thinking and creative thinking in students has not been found. Though critical thinking and creative must be owned by an undergraduate student [14] [15]. Moreover, Universitas Negeri
Yogyakarta is the only educational institution among 20 universities in Indonesia that is eligible for entry (the most promising university) to the world class [16] so it is better if an initial study is carried out which aims to determine the profile of students' critical and creative thinking at Universitas Negeri Yogyakarta. Based on this background, i would like to conduct a preliminary study research which aims to describe the profile of critical and creative thinking of the undergraduate students, especially in the biology education program, Universitas Negeri Yogyakarta.

\section{RESEARCH METHODS}

The purpose of this study is to describe the profiles of critical thinking and creative thinking of the students in the biology education study program, Universitas Negeri Yogyakarta. This research is a quantitative survey research using descriptive data analysis techniques.

\subsection{Time and location}

This research was conducted in August 2020 and located in the undergraduate biology education study program, faculty of mathematic and natural science, Universitas Negeri Yogyakarta.

\subsection{Research Subjects}

The population in this study follows the principle of the Daniel's hypothetical population [17] which consists of all students of the Universitas Negeri Yogyakarta biology education study program, both current, existing and future. To narrow the scope of the study, a representative sample of the hypothetical population was taken. The sampling technique used in this study is the convenience sampling technique, which is the current sample, in this case it consists of 59 students of the Universitas Negeri Yogyakarta biology education study program who are actively studying in semester 3, semester 5 and semester 7 and are willing to become respondents in this study. Conventional sampling is one way of obtaining a nonrandom sample that is carried out on members of the target population who meet certain criteria, such as ease of reach, geographical proximity, availability at a time, or willingness to participate in research [18].

\subsection{Instrument Validity and Reliability}

This study uses a closed questionnaire instrument which is the result of adaptation and modification of the Marzano research instrument for critical and creative habits of mind which has also been developed 
Table 1. Instrument outline of the critical and creative thinking profile

\begin{tabular}{|c|c|l|}
\hline Component & No & \\
\hline Critical Thinking & 1. & Accurate and seeking accuracy \\
\cline { 2 - 3 } & 2. & Clear and seeking clarity \\
\cline { 2 - 3 } & 3. & Open-minded \\
\cline { 2 - 3 } & 4. & Taking a position when there is a guarantee \\
\cline { 2 - 3 } & 5. & Sensitive to other friends \\
\hline Creative Thinking & 1. & Engage intensely in the task even if the solution doesn't appear instantaneous. \\
\cline { 2 - 3 } & 2. & Trying hard to expand own abilities and knowledge \\
\cline { 2 - 3 } & 3. & Creating new point of view outside the common thought \\
\hline
\end{tabular}

by Hidayati and Idris [12] and has been permitted to be used in this study. The research questionnaire consisted of 38 statements, divided into 24 statements to measure students' critical thinking and 14 statements to measure students' creative thinking. This instrument is in the form of a Likert scale with five answers that can be chosen by the students, i.e. strongly agree (SA), agree (A), doubt (D), disagree (DA), and strongly disagree (SDA). The critical thinking and creative thinking research instrument grid is presented in Table 1 [19].

This research instrument was validated using content validity, which is based on the assessment and suggestions by experts in their field [20] and also using empirical validity based on Pearson Product Moment. After testing the validity, it was found that 24 instrument items were declared valid with the highest correlation coefficient value of 0.611 . While the reliability used in this study is to use internal consistency reliability. This reliability is indicated by a number known as the Cronbach Alpha reliability coefficient value by comparing the individual score with the total score [20]. After testing the reliability, the instrument used in this study was stated to be quite satisfactory [21]with a Cronbach's Alpha value of 0.689 .

\subsection{Data Analysis}

The analysis technique used for analyzing student's responses that has been obtained from the questionnaire is descriptive statistical analysis. Data were analized by calculating the respondent's answer score and then calculating the categorization based on the category of the student's critical and creative thinking profile as in Table 2 [22].

\section{RESULT AND DISCUSSION}

After distributing research instruments to students of the Universitas Negeri Yogyakarta biology education undergraduate program, a student's critical thinking and creative thinking profile is obtained which can be seen in Table 3 .

Based on table 3, we can see that the average of all components of the critical thinking profile of students of the undergraduate biology education program of Universitas Negeri Yogyakarta is in the fair category with a score of 71.74. This is in line with the current research performed by Idris which states that profile of undergraduate students' critical thinking in biology education study program at Pekanbaru, Indonesia is in the fair category [10]. From the initial critical thinking test conducted by Khasanah and Octaviani, it was also found that the critical thinking skills of students in the calculus course at Wisnuwardhana University Malang were in a fair category [23]. As a result of students' critical thinking that is not in the high category, students feel ashamed and afraid as well as have lack of confidence in expressing his/her own opinions or asking questions that they do not understand [18]. The indicator with the lowest score in this study is the Taking a position when there is a guarantee which is a component of critical thinking with a score of 64.88 and is still in the fair category. This is followed by the Clear and seeking clarity indicator, which is 69.56, which is also in the fair category. This shows that students are still quite active when involved in discussions in class. In addition, when working on assignments, students' understanding is mediocre in understanding the assignments given.

The indicator with the highest score obtained in this study is the Sensitive to other friends, with a score of 77.97 and followed by the Accurate and seeking accuracy,

Table 2. Score and category of student's critical and creative thinking profile

\begin{tabular}{|c|c|}
\hline Range of Score & Category \\
\hline $75 \leq X<100$ & Good \\
\hline $60 \leq X<75$ & Fair \\
\hline $0 \leq X<60$ & Low \\
\hline
\end{tabular}


Table 3. Critical and creative thinking profiles of the students of biology education program, Universitas Negeri Yogyakarta

\begin{tabular}{|c|c|l|c|}
\hline Component & No & \multicolumn{1}{|c|}{ Indicator } & Total Average \\
\hline \multirow{7}{*}{ Critical Thinking } & 1. & Accurate and seeking accuracy & 76.27 \\
\cline { 2 - 4 } & 2. & Clear and seeking clarity & 69.56 \\
\cline { 2 - 4 } & 3. & Open-minded & 70.00 \\
\cline { 2 - 4 } & 4. & Taking a position when there is a guarantee & 64.88 \\
\cline { 2 - 4 } & 5. & Sensitive to other friends & 77.97 \\
\hline \multirow{2}{*}{ Thinking } & 1. & $\begin{array}{l}\text { Engage intensely in the task even if the solution doesn't appear } \\
\text { instantaneous. }\end{array}$ & 71.74 \\
\cline { 2 - 4 } & 2. & Trying hard to expand own abilities and knowledge & 71.36 \\
\cline { 2 - 4 } & 3. & $\begin{array}{l}\text { Synthesize a new point of view that is different from the } \\
\text { general view }\end{array}$ & 71.73 \\
\hline
\end{tabular}

which is 76.27 , both of which are components of critical thinking that are in the good category. This shows that students can understand the feelings, knowledge, and abilities of their friends well, and also like to give opportunities to their friends to express their opinions in the discussion. In terms of doing assignments, students also pay good attention to accuracy when doing their own assignments.

Based on table 3, it can also be seen that the average of all components of the creative thinking profile is also in a fair category with the average score for all components of creative thinking which is 71.27. This is in line with the findings of Riyadi and Yuliani that the creative thinking of biology education students is in the fair category [24][25]. Ramdani also found that creative thinking in students who take conventional learning is in the fair category [26].

The lowest score on the creative thinking component is the indicator Engage intensely in the task even if the solution doesn't appear instantaneous which gets a score of 70.71 and is followed by the Trying hard to expand own abilities and knowledge indicator which gets a score of 71, 36, these two scores also fall into the fair category. This shows the persistence and tenacity of students who are moderate when they have difficulty doing their assignments. The highest score on the creative thinking indicator is on the Creating new point of view indicator outside the common thought, with a score of 71.73 which is also in the moderate category.
Table 4 shows a profile of critical thinking and creative thinking of undergraduate students of biology education at YSU at different academic levels. In this study, the student academic level was divided into 3 levels, namely level 3, level 5 and level 7 which were calculated based on their active semester status. In general, it can be seen that the academic level does not show a big difference in critical and creative thinking. Because the average student at level 5 has the highest critical thinking, which is 74.41 in the fair category. Then followed by level 3 students with a score of 71.47 in the enough category. The last is level 7 students who have a critical thinking score of 70.10 in a fair category.

Meanwhile, for creative thinking, students with academic level 5 have the highest critical thinking score among others, namely with a score of 73.41 which is included in the fair category. Then followed by students with an academic level of 7 who have a critical thinking score of 71.00 which is included in the fair category. The last is level 3 students who have a creative thinking score of 70.55 which is in the fair category.

From these results it can be seen that the ability of each student's academic level is different even though all of them are at the same level of cognitive development [10]. This is in line with Nikmah's research that the level of critical thinking in each student is not the same [27]. The difference in the academic level of students does not have an effect on differences in critical thinking, because there are factors that have a more significant influence on 
critical thinking in each student, including gender, age, and mother's education level [13]. Likewise with creative thinking, according to Gigih, the ability to think creatively for each person is different [28]. In this study, differences in the academic level of students did not show an effect on differences in creative thinking, this happened because there were many things that had more influence on someone's creative thinking. The factors that play a strong role in influencing the creative thinking of undergraduate

Table 4. Critical thinking and creative thinking profiles of the undergraduate students in biology education study program, Universitas Negeri Yogyakarta based on Semester

\begin{tabular}{|c|c|c|c|}
\hline No & Semester & $\begin{array}{c}\text { Critical } \\
\text { Thinking }\end{array}$ & $\begin{array}{c}\text { Creative } \\
\text { Thinking }\end{array}$ \\
\hline 1. & 3rd & 71.47 & 70.55 \\
\hline 2. & 5th & 74.41 & 73.41 \\
\hline 3. & 7th & 70.10 & 71.00 \\
\hline \multicolumn{2}{|c|}{ Average } & 71.74 & 71.27 \\
\hline
\end{tabular}

students include educational background, parental factors, intelligence and personality [29].

Table 5 shows a profile of critical thinking and creative thinking of undergraduate students of biology education, YSU with different genders. Female students have a critical thinking score, which is 72.08 , which is higher than male students, which is 70.74 , and both are in the fair category. Meanwhile, in creative thinking, male students had a creative thinking score of 73.02 which was higher than female students, namely 70.94 and both of them were also in the moderate category. Based on Table 5, it can be seen that critical thinking in female students tends to be higher than that of male students, this is in accordance with the findings of Arslan that there is a positive relationship between gender and critical thinking. The result, in terms of critical thinking skills of female students was found to be higher than male students [13]. From Table 5 it can also be seen that male students' creative thinking has a score of 73.02 which is in the fair category. Followed by creative thinking female students who have a score of 70.94 which is also included in the enough category. Based on these results, it can be seen that creative thinking in male students tends to be higher than in female students, this is in accordance with the findings of Mashami that overall male students have higher creative thinking skills than female students. Male students showed the ability to generate lots of ideas and the ability to generate ideas that varied higher than the ability of female students [30].
Table 5. Critical thinking and creative thinking profiles of the undergraduate students in biology education study program, Universitas Negeri Yogyakarta based on gender

\begin{tabular}{|c|c|c|c|}
\hline No & Gender & $\begin{array}{c}\text { Critical } \\
\text { Thinking }\end{array}$ & $\begin{array}{c}\text { Creative } \\
\text { Thinking }\end{array}$ \\
\hline 1. & Male & 70.74 & 73.02 \\
\hline 2. & Female & 72.08 & 70.94 \\
\hline
\end{tabular}

\section{CONCLUSION}

The conclusions that can be drawn in this study are the critical thinking of students in the Biology Education Undergraduate Program Universitas Negeri Yogyakarta is in the fair category. Meanwhile, the creative thinking of undergraduate students of the Universitas Negeri Yogyakarta Biology education program is also in the fair category. Student academic level does not have an influence on critical and creative thinking. Based on gender, female students 'critical thinking was higher than male students, while male students' creative thinking was higher than female students.

\section{REFERENCES}

[1] K. Schwab, The Fourth Industrial Revolution: What It Means and How to Respond, World Econ. Forum, 2016, pp. 1-7.

[2] H.A.R. Tilaar, Manajemen Pendidikan Nasional: Kajian Pendidikan Masa Depan, Remaja Rosdakarya, 2004.

[3] I. W. Redhana, Menyiapkan lulusan fmipa yang menguasai keterampilan abad XXI, in: Proceeding Seminar Nasional FMIPA UNDIKSHA V, 2015, pp. 138-155.

[4] National Education Association, Preparing 21st Century Students for a Global Society: An Educator's Guide to The Four Cs, 2010.

[5] P. Griffin, E. Care, The ATC21S Method, 2015.

[6] The Partnership for 21st Century Learning, Framework for 21 st Century Learning - 2 Pager, Partnersh. 21st Century Learning, 2015. DOI: https://doi.org/10.2307/3588214

[7] L. N. Nabilah, Pengembangan Keterampilan Abad 21 dalam Pembelajaran Fisika di Sekolah Menengah Atas Menggunakan Model Creative 
Problem Solving, 2020. DOI: https://doi.org/10.31219/osf.io/6vwhd

[8] M. Surianti, Development of Accounting Curriculum Model Based on Industrial Revolution Approach, Research Journal of Finance Accounting 11 (2) (2020) 116-123. DOI: https://doi.org/10.7176/RJFA/11-2-12

[9] I. P. A. Abad, W. Setianingsih, LPTK dan Profesionalisme Calon Guru, Prosiding Profesionalisme Guru, 2018, pp. 79-88.

[10] T. Idris, Profil Berpikir Kritis Mahasiswa Program Studi Pendidikan Biologi Se-Kota Pekanbaru, Bioedusiana, 2019. DOI: https://doi.org/10.34289/277898

[11] Kardoyo, A. Nurkhin, Muhsin, H. Pramusinto, Problem-Based Learning Strategy: Its Impact on Students' Critical and Creative Thinking Skills, European Journal Educational Research 9(3) (2020) 1141-1150. DOI: https://doi.org/10.12973/eu-jer.9.3.1141

[12] N. Hidayati, T. Idris, Students' Habits of Mind Profiles of Biology Education Department at Public and Private Universities in Pekanbaru, Indonesia, International Journal Instruction 13(2) (2020) 407-418. DOI: https://doi.org/10.29333/iji.2020.13228a

[13] R. Arslan, H. Gulveren, E. Aydin, A Research on Critical Thinking Tendencies and Factors that Affect Critical Thinking of Higher Education Students, International Journal of Business and Management 9(5) (2014) 43-59. DOI: https://doi.org/ 10.5539/ijbm.v9n5p43

[14] N. Santi, M. A. Soendjoto, A. Winarti, Kemampuan Berpikir Kritis Mahasiswa Pendidikan Biologi Melalui Penyelesaian Masalah Lingkungan, BIOEDUKSI Jurnal Pendidikan Biologi 11(1) (2018) 35-39. DOI: https://doi.org/10.20961/bioedukasiuns.v11i1.19738

[15] K. W. Anom, M. Sukaryawan, M. E. Haryani, Pengembangan dan Validasi Instrumen Evaluasi Literasi Lingkungan, Jurnal Penelitian Pendidikan Kimia: Kajian Hasil Penelitian Pendidikan Kimia 5(1) (2018) pp. 57-67.

[16] U. N. Yogyakarta, Sejarah Universitas Negeri Yogyakarta, (n.d.), Accessed on: Sept 2020, [Online].

Available: https://www.uny.ac.id/profil/sejarah-uny
[17] B. Streitberg, W. W. Daniel, Applied Nonparametric Statistics., Biometrics, 1991. DOI: https://doi.org/10.2307/2532422

[18] I. Etikan, Comparison of Convenience Sampling and Purposive Sampling, American Journal Theoretical Applied Statistics 5(1) (2016) 1. DOI: https://doi.org/10.11648/j.ajtas.20160501.11

[19] R. J. Marzano, A Different Kind of Classroom: Teaching with Dimensions of Learning, Association for Supervision and Curriculum Development, 1992.

[20] N. J. Salkind, Statistics for people who (think they) hate statistics: Using Microsoft Excel 2016, Sage Publising, 2017.

[21] K. S. Taber, The Use of Cronbach's Alpha When Developing and Reporting Research Instruments in Science Education, Research in Science Education, 2018.2 DOI: https://doi.org/10.1007/s11165-016-9602-2

[22] S. Y. Seventika, Y. L. Sukestiyarno, S. Mariani, Critical thinking analysis based on Facione (2015) - Angelo (1995) logical mathematics material of vocational high school (VHS), Journal of Physics Conference Series, vol. 983, IOP Publising, Bristol, 2018. DOI: https://doi.org/10.1088/1742-6596/983/1/012067

[23] F. Khasanah, C. T. Octavianti, Peningkatan Kemampuan Berfikir Kritis Mahasiswa Melalui Pembelajaran Savi dengan Mengoptimalkan Math Expert, UNION Jurnal Ilmu Pendidikan $\begin{array}{llll}\text { Matematika } & 5(2) \quad \text { (2017) } 143 . & \text { DOI: }\end{array}$ https://doi.org/10.30738/.v5i2.1219

[24] A. S. Riyadi, Dharmono, A. Naparin, M. Zaini, Kemampuan Berpikir Kreatif Mahasiswa Pendidikan Biologi dalam Penyelesaian Masalah Ekologi Tumbuhan, BIOEDUKASI Jurnal Pendidikan Biologi 11(1) (2018) 29-34.

[25] A. Yuliani, A. Naparin, M. Zaini, Kemampuan Berpikir Kreatif Mahasiswa Pendidikan Biologi dalam Penyelesaian Masalah Ekologi Tumbuhan, Jurnal Pendidikan Biologi 11(1) (2018) 29-34.

[26] I. P. A. A. Ramdani, Keterampilan Berpikir Kreatif Mahasiswa dalam Pembelajaran IPA Menggunakan Model Inkuiri Terbuka, Jurnal Pendidikan Sains Indonesia 8(1) (2020) 1-9. DOI: https://doi.org/10.24815/jpsi.v8i1.15394 
[27] B. Nikmah, A. Pp, S. Amintarti, Profil Berpikir Kritis Mahasiswa dalam Penyelesaian Masalah Mikrobiologi, Proceeding Biology Education Conference, Universitas Sebelas Maret, Surakarta, vol. 14, 2018, p. 5742.

[28] Y. Gigih Maharga, P. Wijayanti, Kemampuan Berpikir Kreatif Siswa SMP dalam Menyelesaikan Soal Open Ended Ditinjau Dari Kemampuan Matematika, MATHEdunesa 8(2) (2019).

[29] P. Tep, S. Maneewan, S. Chuathong, M. A. Easter, A review of influential factors affecting undergraduate students' creative thinking, in: RAIS Conference in: Proceedings-The 11th International RAIS Conference on Social Sciences. SSRN Electronic Journal (2018). DOI: https://doi.org/10.2139/ssrn.3303354

[30] R. A. Mashami, Analisis keterampilan berpikir kreatif masyarakat berdasarkan gender, in: Proceeding National Conference: Education Social Science and Humaniora, vol.1, Research and Community Empowerment Institutions (LITPAM), 2019, p. 2. 